\title{
REPUTATION SYSTEM OF C2C E-COMMERCE, BUYING INTEREST AND TRUST
}

\author{
Linda KUSUMA ${ }^{\left(11^{1}\right.}{ }^{*}$, Sri REJEKI ${ }^{2}{ }^{2}$, Robiyanto ROBIYANTO ${ }^{\circledR 3}{ }^{3}$ Lala IRVIANA ${ }^{4}$ \\ 1, 2, ${ }^{3}$ Faculty of Economics and Business, Satya Wacana Christian University, \\ Salatiga 50711, Central Java, Indonesia \\ ${ }^{4}$ Faculty of Economics and Business, Universitas Diponegoro, Semarang 50199, Central Java, Indonesia
}

Received 19 November 2019; accepted 24 January 2020

\begin{abstract}
One form of the development of technology and internet users in Indonesia is the merge of various C2C (Customers to Customers) e-commerce on the marketplace. Bukalapak is one of the examples. This research presents the effects of reputation systems on trust, trust in buying interest, and reputation systems on Bukalapak customers' buying interests. A total of 120 respondents participated and the data were analyzed using structural equation modeling with Amos 20 software. The results show that the reputation system has a higher direct impact compared to the impacts mediated by trust. Therefore, in an effort to increase the buying interest, the sellers should increase their reputation in the reputation system represented in the list of feedback, review, and the badge level in Bukalapak. To marketplace providers, in this case, Bukalapak, there is still a need to increase the customers' trust. Although it is significant, however, it has low impacts both directly and indirectly.
\end{abstract}

Keywords: $\mathrm{C} 2 \mathrm{C}$ marketplace, reputation systems, trust, buying interest, Bukalapak.

JEL Classification: M10, M15.

\section{Introduction}

Currently, the development of technology and internet users in Indonesia is not only used to gain information but also to meet other needs, i.e. to do the e-commerce activities. E-commerce helps the buying and selling process. C2C (to) e-commerce on the marketplace is currently a very active segment. In Indonesia, there are various $\mathrm{C} 2 \mathrm{C}$ emerging-commerce such as Bukalapak, Tokopedia, OLX, and Berniaga. Bukalapak is one of the most developing marketplaces, after Tokopedia. Bukalapak is in the $9^{\text {th }}$ place for the most accessed site in Indonesia with average page views/users as high as 7.06 and the length of time in the site of 10 minutes.

In Bukalapak, anyone can open an online store. It provides service for customers across Indonesia for both individual and wholesale. Most of them are not professionals and have various backgrounds. Bukalapak has a slogan of "cheap and trusted online selling and buying process" because it gives a $100 \%$ cash guarantee to the customers if the seller did not send the purchased items. Bukalapak has the vision to be the number one marketplace in
Indonesia. By a vision of "empowering SMEs in Indonesia". Bukalapak uses a joint account where all transactions go through their bank account to prevent scam cases that recently happen in online transactions.

In a marketplace such as Bukalapak, there is a reputation system, in a feedback system, in the form of recommendation which is a confirmation system to validate that the item has been already received by the customers. The amount of feedback represents the level of badge given by Bukalapak to the customers. The higher the badge level, the better the reputation which results in an increase in the badge level. The sellers (pelapak) need to collect positive feedbacks from their transactions (the more the better). The badge levels are divided into the following: 1-10 is "BL user", 11-100 is "Seller", 101-500 is "Big Seller", 501-1,000 is "Prospective Boss" or "Calon Juragan", 1,0015,000 is "Boss" or "Juragan", 5,001-10,000 is "Good seller", $10,001-50,000$ is "Recommended Seller", $50.001-100,000$ is "Trusted Seller", and more than 100,000 is "Top Seller". This system is expected to show the trust level of customers to Bukalapak.

*Corresponding author. E-mail: linda.kusuma.uksw@gmail.com 
In online transactions, trust, price, and promotion are several factors influencing online buying demand. Trust is important because in a transaction with no face-to-face meeting can lead to speculation from both the customers and sellers (Grabner-Kraeuter, 2002; Tassawa, 2019). It is also the most important factor that influences the decision and demand to buy things online (Mohmed, Azizan, \& Jali, 2013; Zou, 2018).

Regarding online transactions, the commitment-trust theory of relationship marketing can be applied. The commitment-trust theory of relationship marketing states there is two fundamental factors, i.e. trust and commitment, which must exist for a relationship to be successful. Unfortunately, this theory emerged in the traditional setting, so it must in the new setting area such as an online transaction.

A reliable and trusted trading environment is an important aspect of the success of online markets. The reputation system is an important part to facilitate and maintain trust in the online markets (Juntiwasarakij, 2018; Sriram, Phouzder, Mathew, \& Hungund, 2019). In research by Thompson and Haynes (2017), it was found that the reputation system had a significant positive impact on the demand in online transactions. The finding shows that the better the reputation, the higher the demand for transactions.

Chen et al. (2018) stated that there was a significant link between the reputation of the seller and the buying interest, where a high reputation also equals to high interest to buy. However, in research conducted by Tadelis (2016), it was found that the customers had less intention to report the quality of the sellers through the feedback system. Only half of the customers give feedback, and most of them are positive feedbacks, which in turn decreases the market activity. This could potentially be a factor that prevents the customers to give feedback and decreases the trust of the customers.

This study scrutinizes the effect of reputation system on buying interest in the Indonesian marketplace which is Bukalapak. Bukalapak also has a reputation system through feedback. The system can and must be filled by the customers once they receive the item. If the customers don't fill the feedback form, then it is automatically considered as positive feedback. Once the customers have passed the time limit to confirm, the item status will change to "item received". To the best of the author's knowledge, none study has been done in order to explain the Indonesian marketplace. Also, this study also uses trust as mediating variable, because some previous study i.e. Juntiwasarakij (2018); Sriram et al. (2019) indicates that trust is an important factor, and could have a role as mediating variable (Li et al., 2016).

The aim of this study is to analyze the effect of the reputation system toward buying interest through trust as a mediating variable. The study found that the reputation systems affect trust significantly and trust also significantly affects the buying interest, either directly or through the mediation of the trust variable. The contribution of this study is to help academics in the development of marketing science, particularly knowledge of buying interest in $\mathrm{C} 2 \mathrm{C}$ e-commerce. In addition, this study is also expected to be a reference in future researches.

\section{Literature review}

\subsection{Reputation system}

Reputation is formed as a result of the evaluation of interactions (Thompson \& Haynes, 2017). If interaction does not happen, the reputation of someone will be based on others' references who have the experience (Dhanapal, Vashu, \& Subramaniam, 2015). In the case of the buying and selling process, to understand the sellers' reputation, the customers usually ask for a reference from other customers that have interacted with the seller in the past (Luo, Ba, \& Zhan, 2012). Most of the systems in e-commerce are very simple, where it will rate the sellers' reputation based on the feedback or level of satisfaction given by the customers after interacting with the sellers. Therefore, the level of reputation of a seller is the average of the satisfaction level that the sellers get (Tadelis, 2016). In the Bukalapak reputation system, the higher the badge level, the better the reputation in the eyes of the customers. To increase the badge level, the sellers need to accumulate positive feedbacks from as many transactions as possible.

\subsection{Trust}

When someone shops online, the main thing he/she considers is whether or not he/she trusts the website that provides online shopping services (Luo et al., 2012). The trust of the sellers towards online shopping website depends on its popularity (Jones \& Leonard, 2008; Li et al., 2016). The more popular it gets, the more trust the sellers have. The trust of the customers on the sellers depends on their ability to provide a safe transaction and to ensure that it will be directly processed after the payment is completed (Grabner-Kraeuter, 2002; Setyawan, Susila, \& Anindita, 2019). This reliability is related to the presence of online sellers. Along with technology development, there are more scam-based motives in online shopping activities. There are many fake sellers that also sell fake products. Trust is formed through three dimensions: (1) ability - the competence and characteristics of the seller, which in this case is on how the sellers give service and safety in the form of transactions; (2) benevolence - the sellers' willingness in giving satisfaction that benefits both parties; and (3) integrity - the seller's behavior in running his/her business represented by the real/factual information given to the customers (Schoorman, Mayer, \& Davis, 2007).

\subsection{E-commerce}

E-commerce is a part of e-business which includes the buying and selling process of products and services through the internet (Mohmed et al., 2013; Sinha \& Singh, 2017). 
This includes the activities that support market transactions, such as advertisement, marketing, customer support, safety, shipment, and payment (Sriram et al., 2019). E-commerce refers to the use of the internet and websites in making transactions. In other words, it is a digital activity that gives the possibility for commercial transactions between organizations and individuals. E-commerce is available and can be used anywhere and anytime. The result is called marketspace which goes through the traditional boundaries and is not depend on temporal and geographical locations (Ye et al., 2013).

\subsection{Buying interest}

Buying interest is a component of consumer behavior, and a tendency to act before the decision is carried out (Zou, 2018). It is acquired from the process of learning and thinking that forms perception. It creates a motivation towards what the consumer is thinking, which in the end when the consumer needs to fulfill his/her needs, they will need to actualize what they are thinking. It has a link to feelings and emotions where if someone is happy and satisfied in buying a product, then it will strengthen the buying interest. Buying interest is based on several factors such as expected income, price, and benefits.

\subsection{Hypotheses development}

\subsubsection{Relationship between reputation system and trust}

A trusted commercial environment is very important in online markets. The reputation system becomes an important part to help, shape, and maintain trust in online markets (Mohmed et al., 2013; Tadelis, 2016). However, the policy of eBay that forces customers to revoke their negative feedbacks and only allowing positive feedbacks, according to Jøsang (2007), would also result in the decrease of market activity and potentially prevent customers to leave feedback which then decreased the trust of the customers. If the feedback portrays the satisfaction of the customers in an honest way without any system that forces them to provide certain feedbacks, then it will increase the trust in the online website.

Therefore, the first hypothesis that can be proposed is as follows:

H1: Reputation systems have a positive impact on trust.

\subsubsection{Relationship between trust and buying interest}

In online transactions, trust has a great impact on online buying interest (Jones \& Leonard, 2008; Jøsang, 2007). Trust is the strongest factor in influencing online buying interest and also in the decision making process (Mohmed et al., 2013). If an online shop is already trusted, then the customers will be interested to buy things online on the site. Therefore, the second hypothesis that can be proposed is as follows:

$\mathrm{H} 2$ : Trust has a positive impact on buying interest.

\subsubsection{Relationship between reputation system and trust with buying interest}

If reputation systems portray satisfaction in an honest way without any system that drives a few sellers and there is no manipulation in the system, it will increase trust that will simultaneously impact the buying interest (Jøsang, 2007; Mohmed et al., 2013; Tadelis, 2016). Therefore, the third hypothesis that can be proposed is as follows:

$\mathrm{H} 3$ : The reputation system has a positive impact on buying interest.

\section{Method}

The dependent variable was buying interest, the independent variable was the reputation system and, the moderating variable was trust (X2). The research framework of this study can be seen in Figure 1.

The data used in this study was the primary data from the questionnaire. The population of this study was all internet users in Salatiga that had used the internet to shop online. To determine the samples, a criterion was set: anyone that had accessed Bukalapak. The research framework developed has 24 parameters. Therefore, the minimum sample that must be met was 120 respondents. In fact, a total of 150 questionnaires were distributed to prevent the ones which did not meet the standard. The respondents were asked to answer the questionnaire items whose answers ranging from agreeing to disagree scale.

The structural equation model (SEM) was used to analyze the data which enabled the researchers to answer the research questions that were either regressive or dimensional. The concept and operational definitions in this study is shown in Table 1.

$\mathrm{H} 3$

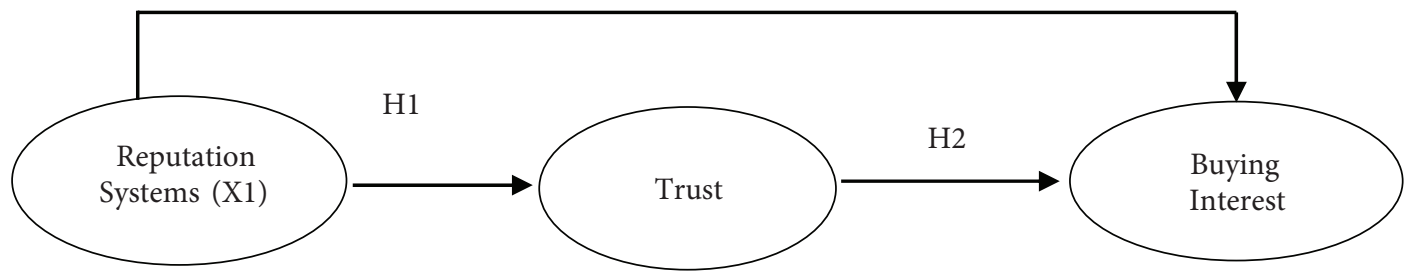

Figure 1. Model specification 
Table 1. Concept and operational definition (source: adapted from Mohmed et al., 2013)

\begin{tabular}{|c|c|c|}
\hline Variable & Conceptual definition & Indicators \\
\hline $\begin{array}{l}\text { Repu- } \\
\text { tation } \\
\text { System }\end{array}$ & $\begin{array}{l}\text { A system constructed in e-commerce applications which } \\
\text { are mostly very simple and will judge sellers' reputation } \\
\text { according to the feedbacks or satisfaction levels given by } \\
\text { the customers to the sellers after doing the transaction. } \\
\text { Therefore, the reputation score is the average score from } \\
\text { satisfaction that the sellers get (Jøsang, 2007; Tadelis, 2016) }\end{array}$ & $\begin{array}{l}\text { - A seller's reputation represented by accumulated feedback. } \\
\text { - Feedback shows the satisfaction level of the customers. } \\
\text { - Reputation becomes a reference to choose sellers. } \\
\text { - The higher the reputation, the better the rate they will get. } \\
\text { - The higher the quantity of the feedback, the better the rate. }\end{array}$ \\
\hline Trust & $\begin{array}{l}\text { Trust is formed through three dimensions: (1) ability - } \\
\text { the competence and characteristics of the seller, which } \\
\text { in this case is on how the sellers give service and safety } \\
\text { in the form of transactions; (2) benevolence - the sellers' } \\
\text { willingness in giving satisfaction that benefits both parties; } \\
\text { and (3) integrity - the seller's behavior in running his/her } \\
\text { business represented by the real/factual information given } \\
\text { to the customers (Schoorman et al., 2007). }\end{array}$ & $\begin{array}{l}\text { - Fully trust the transaction process. } \\
\text { - Fully trust the website when giving personal information. } \\
\text { - Fully trust the information presented on the seller's website. } \\
\text { - Fully trust the safety of the transaction. } \\
\text { - Fully trust the number of feedback a seller has. } \\
\text { - Fully trust the reputation point of the seller. } \\
\text { - Fully trust the seller that has high feedback scores. }\end{array}$ \\
\hline $\begin{array}{l}\text { Buying } \\
\text { Interest }\end{array}$ & $\begin{array}{l}\text { Buying interest creates a motivation towards what } \\
\text { the consumer is thinking, which in the end when the } \\
\text { consumer needs to fulfill his/her needs, they will need to } \\
\text { actualize what they are thinking. It has a link to feelings } \\
\text { and emotions where if someone is happy and satisfied } \\
\text { in buying a product, then it will strengthen the buying } \\
\text { interest (Jones \& Leonard, 2008) }\end{array}$ & $\begin{array}{l}\text { - Good seller reputation will give the incentive to find more } \\
\text { information related to the product. } \\
\text { - A high reputation level will incentivize people to buy } \\
\text { products. } \\
\text { - A good seller reputation will give the incentive to topple } \\
\text { down the first choice in buying products. } \\
\text { - Willing to spend money on a website because they trust the } \\
\text { seller. } \\
\text { - Willing to buy a product after seeing the number of } \\
\text { feedbacks. } \\
\text { - Willing to recommend the website/seller to other people. }\end{array}$ \\
\hline
\end{tabular}

Table 2. Results of validity and reliability test (source: Primary data, processed)

\begin{tabular}{|c|c|c|c|c|c|c|}
\hline \multirow[b]{2}{*}{$\frac{\stackrel{0}{\pi}}{\stackrel{\pi}{\pi}}$} & \multirow{2}{*}{ 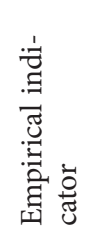 } & \multirow[b]{2}{*}{ 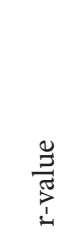 } & \multirow[b]{2}{*}{ 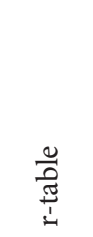 } & \multirow{2}{*}{$\frac{\text { Validity }}{\text { 年 }}$} & \multirow{2}{*}{$\begin{array}{c}\text { Cron- } \\
\text { bach's } \\
\alpha\end{array}$} & $\begin{array}{l}\text { Relia- } \\
\text { bility }\end{array}$ \\
\hline & & & & & & 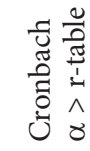 \\
\hline \multirow{8}{*}{$\begin{array}{l}\text { Repu- } \\
\text { tation } \\
\text { System }\end{array}$} & RS1 & 0.764 & 0.1339 & Valid & \multirow{8}{*}{0.903} & \multirow{8}{*}{$\begin{array}{l}\text { Re- } \\
\text { liable }\end{array}$} \\
\hline & RS2 & 0.757 & 0.1339 & Valid & & \\
\hline & RS3 & 0.755 & 0.1339 & Valid & & \\
\hline & RS 4 & 0.783 & 0.1339 & Valid & & \\
\hline & RS 5 & 0.846 & 0.1339 & Valid & & \\
\hline & RS 6 & 0.784 & 0.1339 & Valid & & \\
\hline & RS 7 & 0.763 & 0.1339 & Valid & & \\
\hline & RS 8 & 0.784 & 0.1339 & Valid & & \\
\hline \multirow{9}{*}{ Trust } & T1 & 0.781 & 0.1339 & Valid & \multirow{9}{*}{0.925} & \multirow{9}{*}{$\begin{array}{l}\text { Re- } \\
\text { liable }\end{array}$} \\
\hline & T2 & 0.791 & 0.1339 & Valid & & \\
\hline & T3 & 0.829 & 0.1339 & Valid & & \\
\hline & T4 & 0.860 & 0.1339 & Valid & & \\
\hline & T5 & 0.735 & 0.1339 & Valid & & \\
\hline & T6 & 0.741 & 0.1339 & Valid & & \\
\hline & T7 & 0.762 & 0.1339 & Valid & & \\
\hline & T8 & 0.822 & 0.1339 & Valid & & \\
\hline & T9 & 0.805 & 0.1339 & Valid & & \\
\hline \multirow{7}{*}{$\begin{array}{l}\text { Interest } \\
\text { to buy }\end{array}$} & MB1 & 0.829 & 0.1339 & Valid & \multirow{7}{*}{0.901} & \multirow{7}{*}{$\begin{array}{l}\text { Re- } \\
\text { liable }\end{array}$} \\
\hline & MB2 & 0.831 & 0.1339 & Valid & & \\
\hline & MB3 & 0.789 & 0.1339 & Valid & & \\
\hline & MB4 & 0.817 & 0.1339 & Valid & & \\
\hline & MB5 & 0.750 & 0.1339 & Valid & & \\
\hline & MB6 & 0.844 & 0.1339 & Valid & & \\
\hline & MB7 & 0.730 & 0.1339 & Valid & & \\
\hline
\end{tabular}

\section{Result}

Before analyzing the data using SEM, the data were examined using SPSS to see the validity and reliability of the indicators. The results could be seen in Table 2.

Based on Table 2, it could be concluded that the data was valid and reliable. Therefore, data processing could be continued.

\subsection{Data selection}

A total of 150 questionnaires were distributed to 150 people in Salatiga that had accessed Bukalapak where 79 of them were distributed in person and the rest 71 were distributed online using Google Form. However, the ones with the highest Mahalanobis distance/score were not included to obtain data normality required and left 120 questionnaires to process. The number of the sample used in this study (120 samples) conforms with Hair et al. (2009)'s recommendation, which is for a model containing five or fewer constructs, each with more than three items, the minimum sample size is 100 .

The respondents' profile includes their gender, age, job, income, type of shops/sellers and whether or not they had experience in purchasing goods and making transactions in Bukalapak. The respondents' profiles can be seen in Table 3.

Table 3. Respondents' profile (source: primary data, processed)

\begin{tabular}{|l|l|c|c|}
\hline Category & \multicolumn{1}{|c|}{ Sub-category } & Frequency & Percentage \\
\hline \multirow{2}{*}{ Gender } & Female & 81 & $67 \%$ \\
& Male & 39 & $33 \%$ \\
\hline \multirow{2}{*}{ Age } & $18-23$ & 117 & $97 \%$ \\
& $24-29$ & 3 & $3 \%$ \\
\hline
\end{tabular}


End of Table 3

\begin{tabular}{|c|c|c|c|}
\hline Category & Sub-category & Frequency & Percentage \\
\hline Job & $\begin{array}{l}\text { Private sector workers } \\
\text { High school / college } \\
\text { students } \\
\text { Entrepreneur }\end{array}$ & $\begin{array}{c}13 \\
106 \\
1\end{array}$ & $\begin{array}{r}11 \% \\
88 \% \\
1 \%\end{array}$ \\
\hline $\begin{array}{l}\text { Type of } \\
\text { seller } \\
\text { visited }\end{array}$ & $\begin{array}{l}\text { Automotive } \\
\text { others } \\
\text { Electronic store } \\
\text { Clothing store } \\
\text { General store }\end{array}$ & $\begin{array}{c}3 \\
2 \\
25 \\
57 \\
33\end{array}$ & $\begin{array}{c}2 \% \\
2 \% \\
21 \% \\
47 \% \\
28 \% \\
\end{array}$ \\
\hline $\begin{array}{l}\text { Have/ } \\
\text { haven't } \\
\text { shopped in } \\
\text { bukalapak }\end{array}$ & $\begin{array}{l}\text { Yes } \\
\text { No }\end{array}$ & $\begin{array}{l}40 \\
80\end{array}$ & $\begin{array}{l}31 \% \\
69 \%\end{array}$ \\
\hline Income & $\begin{array}{l}\text { Less than IDR 500,000 } \\
\text { IDR 500,000 - IDR } \\
999,000 \\
\text { IDR } 1,000,000 \text { - IDR } \\
1,449,000 \\
\text { IDR } 1,500,000 \text { - IDR } \\
1,999,000 \\
\text { More than IDR } \\
2,000,000\end{array}$ & $\begin{array}{l}26 \\
41 \\
\\
26 \\
11 \\
\\
16\end{array}$ & $\begin{array}{r}22 \% \\
34 \% \\
22 \% \\
9 \% \\
13 \%\end{array}$ \\
\hline
\end{tabular}

\subsection{Data analysis}

Before examining the direct/indirect impact, evaluation of SEM assumptions in the form of analysis on the suitability of the model proposed was done with various criteria of goodness of fit indices and data normality. To acquire sufficient conformity, the structural equation model had been modified once. The modification was done after the output show that the model was fit. The modification was done as the previous model was not considered fit. The original version of the proposed model can be seen in Figure 2 .

Based on Figure 2, it can be seen that the model is not fit for the goodness of fit indices used. Figure 3 shows a better version of the model.

The revised version of the model shows that it has a good fit for the goodness of fit indices which aims to understand how far the model that is hypothesized fits/ conforms with the sample. The results of the goodness of fit indices can be seen in Table 4 .

The results show that the model has a value of ChiSquare $=53.725, \mathrm{Cmin} / \mathrm{df}=1.310$ Probability $=0.088$, $\mathrm{GFI}=0.9929, \mathrm{CFI}=0.989, \mathrm{AGFI}=0.885, \mathrm{TLI}=0.985$,

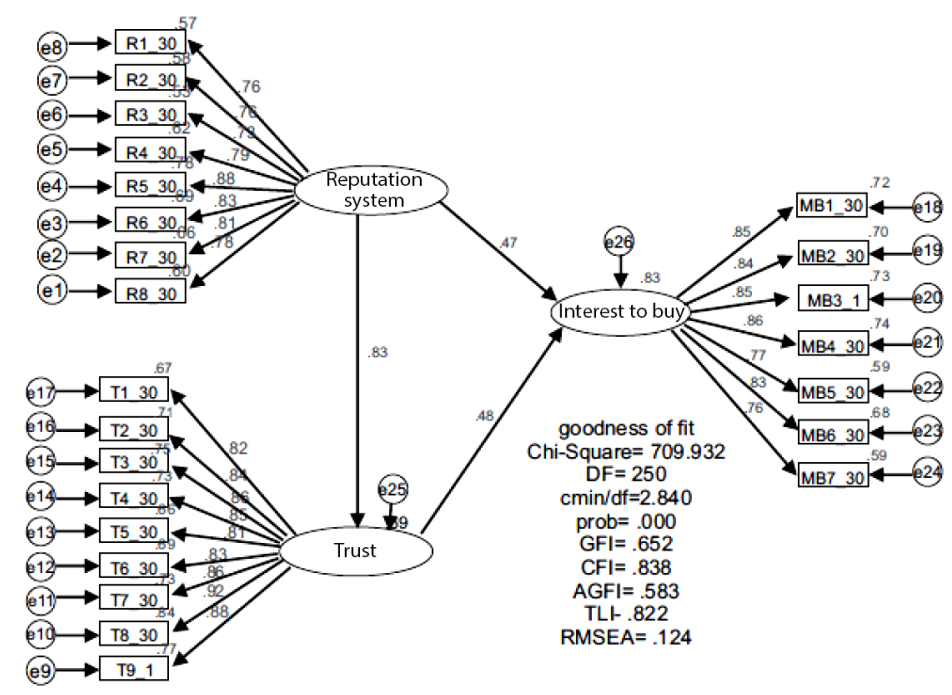

Figure 2. The initial model (source: primary data, processed)

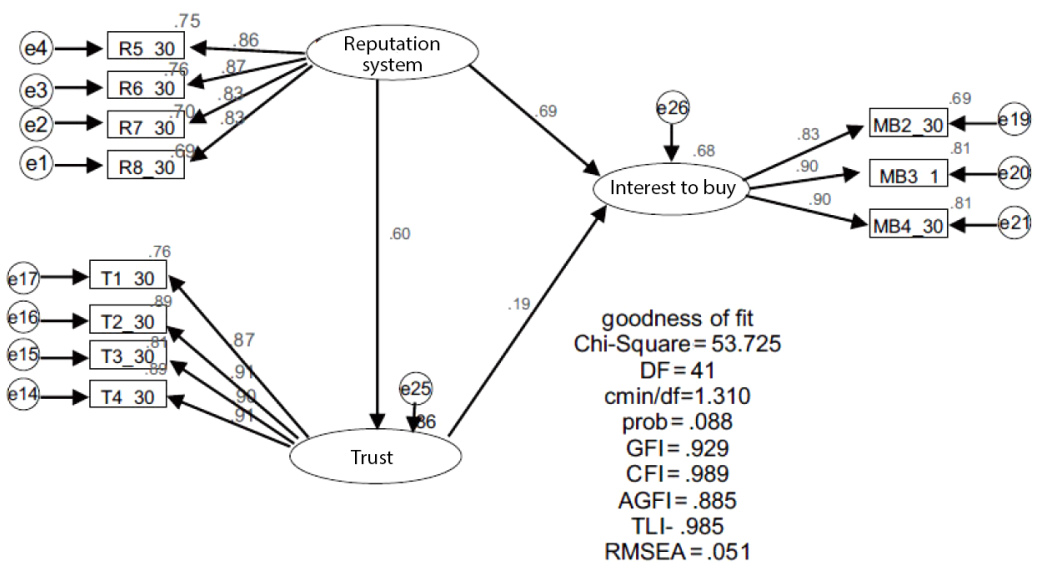

Figure 3. The revised model (source: primary data, processed) 
Table 4. Result of goodness of fit indices (source: primary data, processed)

\begin{tabular}{|l|c|c|l|}
\hline GOF Indices & Cut-off Value & Result & Conclusion \\
\hline Chi-Square & Small & 53.725 & Good Fit \\
\hline Cmin/df & $\leq 2.00$ & 1.310 & Good Fit \\
\hline Probability & $\geq 0.05$ & 0.088 & Good Fit \\
\hline GFI & $\leq 0.90$ & 0.929 & Good Fit \\
\hline CFI & $\geq 0.95$ & 0.989 & Good Fit \\
\hline AGFI & $\geq 0.90$ & 0.885 & Marginal Fit \\
\hline TLI & $\geq 0.95$ & 0.985 & Good Fit \\
\hline RSMEA & $0.03-0.08$ & 0.051 & Good Fit \\
\hline
\end{tabular}

and RSMEA $=0.051$. The whole model shows good levels of conformity. Therefore, it can be stated that the model is fit and the data fits the model to examine. Although the AGFI value is considered in the marginal category, it meets the criteria and the value is not too far from the expected value.

\subsection{Causality examination (regression weight)}

The relationships between variables could be seen on its significance value on its critical ratio (c.r) and the significance probability. Table 5 presents the analysis result.

Table 5. Regression weights (source: primary data, processed)

\begin{tabular}{|l|c|c|c|c|c|c|c|}
\hline & & & Estimate & S.E. & C.R. & P & Label \\
\hline Trust & $<---$ & $\begin{array}{l}\text { Repu- } \\
\text { tation } \\
\text { System }\end{array}$ & .578 & .089 & 6.485 & $\star * *$ & par_9 \\
\hline $\begin{array}{l}\text { Buying } \\
\text { Interest }\end{array}$ & $<---$ & $\begin{array}{l}\text { Repu- } \\
\text { tation } \\
\text { System }\end{array}$ & .626 & .087 & 7.182 & $* * *$ & par_10 \\
\hline $\begin{array}{l}\text { Buying } \\
\text { Interest }\end{array}$ & $<---$ & Trust & .181 & .080 & 2.264 & .024 & par_11 \\
\hline
\end{tabular}

The hypothesis testing was done by analyzing the C.R and p-value. The cut-off value of C.R. should be more than 1.96 , while the p-value should be less than 0.05 . If the results meet the criteria, the hypothesis is supported and vice versa. Table 6 explains the results of hypotheses testing.

Table 6. Results of hypotheses testing (source: primary data, processed)

\begin{tabular}{|l|l|}
\hline \multicolumn{1}{|c|}{ Hypothesis } & Conclusion \\
\hline $\begin{array}{l}\text { H1: Reputation systems have a positive impact } \\
\text { on trust }\end{array}$ & Significant \\
\hline $\begin{array}{l}\text { H2: Trust has a positive impact on buying } \\
\text { interest }\end{array}$ & Significant \\
\hline $\begin{array}{l}\text { H3: The reputation system has a positive } \\
\text { impact on buying interest }\end{array}$ & Significant \\
\hline
\end{tabular}

The results of the coefficient of determination $\left(\mathrm{R}^{2}\right)$ of the model show the influence of the independent variables to the dependent variable which represents the way it influences. Table 7 shows the coefficient determination of trust and buying interest variable.

Tabel 7. Coefficient of determination (Squared multiple correlation) (source: primary data, processed)

\begin{tabular}{|l|c|}
\hline \multicolumn{1}{|c|}{ Variable } & Estimate \\
\hline Trust & 0.363 \\
\hline Buying Interest & 0.680 \\
\hline
\end{tabular}

Table 7 shows that trust and reputation systems impact the buying interest as much as $68 \%$. On the other hand, the reputation system impacts trust as much as $36.3 \%$. This indicated that the proportion of influence given by the independent variables on the dependent variable was quite high, and the rest was influenced by other variables not included in the study.

\subsection{Direct, indirect and total effect}

The direct effect was a result of the estimation of the influences of the parameter value between independent and dependent variables. The indirect effect was an influence from an exogenous variable towards endogenous dependent through endogenous intervening variables. Meanwhile, the total effect is the sum of both direct and indirect effects. Table 8 presents the direct, indirect and total effects of the variables.

Table 8. Direct, indirect, and total effect (source: primary data, processed)

\begin{tabular}{|l|c|c|c|}
\hline & $\begin{array}{c}\text { Direct } \\
\text { Effect }\end{array}$ & $\begin{array}{c}\text { Indirect } \\
\text { Effect }\end{array}$ & $\begin{array}{c}\text { Total } \\
\text { Effect }\end{array}$ \\
\hline Reputation System $\rightarrow$ Trust & 0.603 & 0.000 & 0.603 \\
\hline Trust $\rightarrow$ Buying Interest & 0.193 & 0.000 & 0.193 \\
\hline $\begin{array}{l}\text { Reputation System } \rightarrow \\
\text { Buying Interest }\end{array}$ & 0.694 & 0.116 & 0.810 \\
\hline
\end{tabular}

The direct effect of the reputation system on trust is 0.603 , trust on buying interest is 0.193 and reputation systems on buying interest is 0.694 . Meanwhile, the indirect effect of the reputation system on buying interest through trust is 0.116 . The total effect between variables is the total effect of the reputation system on buying interest mediated by the trust which is 0.810 .

\section{Discussion}

\subsection{The effect of reputation system on trust}

A reputation system has a positive and significant effect on trust (0.578). It indicates that the reputation system was one of the factors needed to increase the customers' trust in the sellers. The respondents observed and considered every feedback when they saw a product. In other words, they also judged the sellers' reputation which could be seen from the feedbacks and badge level. Generally, the 
respondents implied that the feedback portrayed the customers' satisfaction. Its reputation system had an influence on trust with a quite high score (0.603). It indicated that the increase in the reputation system would give a direct impact on trust. This is in line with Jones and Leonard (2008), Jøsang (2007); Tadelis (2016) which stated that the reputation systems had an important role to form and maintain trust in online markets.

\subsection{The effect of trust on buying interest}

Trust has a positive and significant impact on buying interest $(0.181)$ where previously, trust is influenced by reputation systems. The customers' trust was represented when they were willing to buy, give personal information, and complete the payment process in Bukalapak. It also indicated that they trusted the Bukalapak interface display. Trust also influenced the buying interest (0.193) which showed that the increase in the trust would affect directly the buying interest. This also showed that all online stores could be trusted, and it was a key factor. Hence, the consumers would be incentivized to buy on the site. The results of this present study are different from research by Mohmed et al. (2013) who found that trust was the strongest factor that affected online buying interest, and also in the process of making decisions. This study found that trust is not the strongest factor. Overall, this finding supports Luo et al. (2012), Zou (2018).

\subsection{The effect of reputation system on buying interest}

The reputation system has a positive and significant influence on buying interest (0.626). It shows that an increase in the reputation system could affect the buying interest. The better the reputation systems, the higher the buying interest. A good reputation made the customers look up for more information on the product which made it easier to decide. It is also shown that the reputation systems also impacted the buying interest directly with a score of 0.694 . It shows that the reputation system had a direct effect on buying interest. This finding supports (Chen et al., 2018; Tadelis, 2016; Thompson \& Haynes, 2017).

\subsection{The effect of reputation system on buying interest mediated by trust}

The reputation system is found to have an influence on buying interest mediated by the trust with an indirect effect value of 0.116 and results in a total effect value of 0.810 . The indirect effect value is smaller than the direct effect (0.694). This shows that although it was significant, trust was still less influential as a mediating variable between reputation system and buying interest. This finding consistent with Jøsang (2007), Li et al. (2016), Ye et al. (2013).

\section{Conclusions}

The reputation system available in Bukalapak significantly affects trust. The trust also significantly affects buying interest. The reputation system also significantly affects the buying interest, both directly and with the mediation of trust. This study shows that the trust variable could influence and add the reputation systems' effect on the buying interest. However, it is statistically lower compared to the direct effects given by the reputation system on the buying interest. Therefore, the effect of trust is smaller on the buying interest. This implied that in the process of increasing the buying interest, instead of increasing the trust, it was necessary to increase the reputation system first.

The results show that the reputation system has a higher direct impact compared to the impacts mediated by trust. Therefore, in an effort to increase the buying interest, the sellers should increase their reputation in the reputation system represented in the list of feedback, review, and the badge level in Bukalapak. To marketplace providers, in this case, Bukalapak, there is still a need to increase the customers' trust. Although it is significant, however, it has low impacts both directly and indirectly. This shows that the level of consumer trust on Bukalapak. com is still low. It is expected that by increasing the consumer's trust, it will give more impacts on the buying interest. In practice, it can make it easier for the customers to determine which sellers can be trusted, and simultaneously increase the buying interest.

Future researches are expected to have more respondents who are not limited to one area. From the operational definition, the researchers developed a questionnaire with 24 questions and still eliminated some of them when the model should be modified. Future researches are expected to make more question items in each variable and increase or replace the questions eliminated in the modifying process. There were several terms in the questionnaire that could not be understood by the respondents despite being helped by several images. Therefore, future researches are expected to only use familiar terms.

This study only examined the effect of reputation system and trust on buying interest based on a phenomenon and previous studies. Future researches are suggested to use similar $\mathrm{C} 2 \mathrm{C}$ e-commerce objects and add more variables such as promotion or competition with other C2C e-commerce in the marketplace in Indonesia such as Tokopedia or even with the $\mathrm{B} 2 \mathrm{C}$ e-commerce in the marketplace in Indonesia.

\section{References}

Chen, R., Zheng, Y., Xu, W., Liu, M., \& Wang, J. (2018). Secondhand seller reputation in online markets: A text analytics framework. Decision Support Systems, 108, 96-106. https://doi.org/10.1016/j.dss.2018.02.008

Dhanapal, S., Vashu, D., \& Subramaniam, T. (2015). Perceptions on the challenges of online purchasing: a study from "baby 
boomers", generation " $\mathrm{X}$ " and generation "Y" point of views. Contaduría y Administración, 60, 107-132. https://doi.org/10.1016/j.cya.2015.08.003

Grabner-Kraeuter, S. (2002). The role of consumers' trust in online-shopping. Journal of Business Ethics, 39(1/2), 43-50. https://doi.org/10.1023/A:1016323815802

Hair, J. F., Black, W. C., Babin, B. J., \& Anderson, R. E. (2009). Multivariate data analysis (7 ed.). Pearson.

Jones, K., \& Leonard, L. N. K. (2008). Trust in consumer-toconsumer electronic commerce. Information \& Management, 45(2), 88-95. https://doi.org/10.1016/j.im.2007.12.002

Jøsang, A. (2007). Trust and reputation systems. Lecture Notes in Computer Science, 209-245. https://doi.org/10.1007/978-3-540-74810-6_8

Juntiwasarakij, S. (2018). Framing emerging behaviors influenced by internet celebrity. Kasetsart Journal of Social Sciences, 39(3), 550-555. https://doi.org/10.1016/j.kjss.2018.06.014

Li, M., Wei, K.-K., Tayi, G. K., \& Tan, C.-H. (2016). The moderating role of information load on online product presentation. Information \& Management, 53(4), 467-480. https://doi.org/10.1016/j.im.2015.11.002

Luo, J., Ba, S., \& Zhan, H. (2012). The effectiveness of online shopping characteristics and well-designed websites on satisfaction. MIS Quarterly, 36(4), 1131-1144. https://doi.org/10.2307/41703501

Mohmed, A. S. I., Azizan, N. B., \& Jali, M. Z. (2013). The Impact of trust and past experience on intention to purchase in ecommerce. International Journal of Engineering Research and Development, 7(10), 28-35. http://www.ijerd.com/paper/vol7-issue10/D07010028035.pdf

Schoorman, F. D., Mayer, R. C., \& Davis, J. H. (2007). An integrative model of organizational trust: past, present, and future. Academy of Management Review, 32(2), 344-354. https://doi.org/10.5465/amr.2007.24348410

Setyawan, A., Susila, I., \& Anindita, S. (2019). Influence of power asymmetry, commitment and trust on SME retailers' perfor- mance. Business: Theory and Practice, 20, 216-223. https://doi.org/10.3846/btp.2019.21

Sinha, P., \& Singh, S. (2017). Comparing risks and benefits for value enhancement of online purchase. Gadjah Mada International Journal of Business, 19(3), 307-327. https://doi.org/10.22146/gamaijb.10512

Sriram, K. V., Phouzder, K., Mathew, A. O., \& Hungund, S. (2019). Does e-marketing mix influence brand loyalty and popularity of e-commerce websites? ABAC Journal, 39(2), 64-81. http://www.assumptionjournal.au.edu/index.php/ abacjournal/article/view/3958

Tadelis, S. (2016). Reputation and feedback systems in online platform markets. http://faculty.haas.berkeley.edu/stadelis/ Annual_Review_Tadelis.pdf

Tassawa, C. (2019). Factors influencing Facebook page post' likes, shares, and comments in sport marketing. ABAC Journal, 39(3), 56-69. http://www.assumptionjournal.au.edu/index.php/abacjournal/article/download/4201/2485

Thompson, S., \& Haynes, M. (2017). The value of online seller reputation: evidence from a price comparison site. Managerial and Decision Economics, 38(3), 302-313. https://doi.org/10.1002/mde.2777

Ye, Q., Xu, M., Kiang, M., Wu, W., \& Sun, F. (2013). In-Depth analysis of the seller reputation and price premium relationship a comparison between ebay US and Taobao China. Journal of Electronic Commerce Research, 14(1). http:// www.jecr.org/sites/default/files/In-Depth\%20Analysis\%20 of $\% 20$ the $\% 20$ Seller $\% 20$ Reputation $\% 20$ and $\% 20$ Price $\% 20$ Premium\%20Relationship\%20\%20A\%20Comparison\%20between\%20Ebay\%20US\%20and\%20Taobao\%20China.pdf

Zou, T. (2018). Online impulse buying behavior amongst undergraduate students in Tianjin, The People's Republic of China. ABAC Journal, 38(2), 94-113. http://www.assumptionjournal. au.edu/index.php/abacjournal/article/view/3574/2183 